\title{
Yield and Quality of Inflorescences in the Zantedeschia albomaculata (Hook.) Baill. 'Albomaculata' after the Treatment with $\mathrm{AMF}$ and $\mathrm{GA}_{3}$
}

\author{
Roman Andrzejak ${ }^{1}$ and Beata Janowska ${ }^{2, *(D)}$ \\ 1 Department of Phytopathology, Seed Science and Technology, Faculty of Agronomy, \\ Horticulture and Bioengineering, Poznań University of Life Sciences, Dąbrowskiego 159, \\ 60-594 Poznań, Poland; roman.andrzejak@up.poznan.pl \\ 2 Department of Ornamental Plants, Dendrology and Pomology, Faculty of Agronomy, \\ Horticulture and Bioengineering, Poznań University of Life Sciences, Dąbrowskiego 159, \\ 60-594 Poznań, Poland \\ * Correspondence: beata.janowska@up.poznan.pl
}

check for updates

Citation: Andrzejak, R.; Janowska, B. Yield and Quality of Inflorescences in the Zantedeschia albomaculata (Hook.)

Baill. 'Albomaculata' after the

Treatment with AMF and $\mathrm{GA}_{3}$.

Agronomy 2021, 11, 644.

https://doi.org/10.3390/

agronomy11040644

Academic Editors: Matteo Caser and John P. Thompson

Received: 27 January 2021

Accepted: 25 March 2021

Published: 27 March 2021

Publisher's Note: MDPI stays neutral with regard to jurisdictional claims in published maps and institutional affiliations.

Copyright: (c) 2021 by the authors. Licensee MDPI, Basel, Switzerland. This article is an open access article distributed under the terms and conditions of the Creative Commons Attribution (CC BY) license (https:/ / creativecommons.org/licenses/by/ $4.0 /)$.

\begin{abstract}
This study was conducted to assess the influence of gibberellic acid $\left(\mathrm{GA}_{3}\right)$ and arbuscular mycorrhizal fungi (AMF) on the flowering and quality of Zantedeschia albomaculata (Hook.) Baill 'Albomaculata' plants. Before planting, the rhizomes were soaked in water or an aqueous solution of $\mathrm{GA}_{3}$ at a concentration of $150 \mathrm{mg} \mathrm{dm}^{-3}$ for $30 \mathrm{~min}$. A mixture of AMF was applied to the rhizomes a week after planting. The AMF treatment increased the yield of inflorescences of the 'Albomaculata' cultivar by $100 \%$. AMF and $\mathrm{GA}_{3}$ had a favourable effect on the quality of inflorescences, expressed by the length of peduncles, whereas AMF individually positively affected the length of the spathes. AMF and $\mathrm{GA}_{3}$ had no effect on the level of macroelements in calla lily leaves, with the exception of calcium (Ca). The leaves of mycorrhized plants had a high content of sodium ( $\mathrm{Na}$ ) and micronutrients, except for iron $(\mathrm{Fe})$. The results of the study showed that $\mathrm{GA}_{3}$ could be replaced by mycorrhizal inoculation when applied to Zantedeschia plants.
\end{abstract}

Keywords: Zantedeschia albomaculata 'Albomaculata'; yield; quality; micro and macroelements; mycorrhization; $\mathrm{GA}_{3}$

\section{Introduction}

Calla lilies-Zantedeschia-are African plants of the Araceae family. They are mostly grown for cut flowers and they rank thirteenth in the flower trade in The Netherlands. Due to unsatisfactory flower harvests mainly because of the high prices of rhizomes produced abroad, Calla lilies are not so popular among Polish producers. Even though the flower yield can be increased with the application of gibberellic acid $\left(\mathrm{GA}_{3}\right)$ [1-6], the risk of contamination via fertilizer solution, such as Pectobacterium carotovorum subsp. carotovorum [7], a pathogen bacteria associated with soft rot, is high and could seriously limit the production.

Therefore, it is advisable to seek other methods to improve the flowering of Zantedeschia cultivars as efficiently as with $\mathrm{GA}_{3}$. According to Matysiak [8], arbuscular mycorrhizal fungi (AMF) stimulates flowering, because it produces growth regulators, including gibberellin. AMF are in symbiotic relationships with most wild and cultivated terrestrial plants except species belonging to the Brassicaceae and Chenopodiaceae families [9]. Mycorrhizal fungi facilitate the uptake of micro- and macronutrients in exchange for photosynthetic products [9].

In addition, AMF facilitates the completion of biogeochemical cycles, increases plant tolerance to biotic and abiotic stresses [10], and increases the phytochemical content of health-promoting compounds [11,12]. Fungal spores germinate at the right humidity, temperature, and $\mathrm{pH}$. However, their vitality is limited [13]. The morphogenesis of fungal 
spores takes place when they encounter host plants [14,15]. Fungal hyphae penetrate the root cells and form arbuscules, through which nutrients can be exchanged between the fungi and the plant $[16,17]$. AMF acquires nutrients for plants, in particular phosphorus in poor environments. In return, the fungi receive the necessary carbohydrates [18].

In this study, we assessed the effects of $A M F$ and $\mathrm{GA}_{3}$ on the flowering and quality of Zantedeschia albomaculata 'Albomaculata' plants. The content of micro- and macronutrients in the leaves was assessed. The assumption was that mycorrhizal fungi would establish a symbiotic relationship with plants and, thus, increase the flower yield and intensify the uptake of nutrients.

\section{Material and Methods}

\subsection{Plants}

This study was conducted to assess the influence of gibberellic acid $\left(\mathrm{GA}_{3}\right)$ and arbuscular mycorrhizal fungi (AMF) on the flowering and quality of Zantedeschia albomaculata (Hook.) Baill. 'Albomaculata' plants. For three consecutive years of research, on 16 May, rhizomes of more than $20 \mathrm{~cm}$ in circumference, with leaf buds of $0.5-1.5 \mathrm{~cm}$ in length, were planted into $20-\mathrm{cm}$ pots with a substrate consisting of peat $(\mathrm{pH}$ 6.2) enriched with a slow-release fertilizer Osmocote Plus (3-4 M) $(15+11+13 \pm 2 \mathrm{MgO}+$ microelements $)$ at an amount of $3 \mathrm{~g} \cdot \mathrm{dm}^{-3}$ and mixed with fresh, shredded pine bark at a 3:1 ratio $(v / v)$.

Before planting, the rhizomes were soaked in water (control plants) or an aqueous solution of gibberellic acid $\left(\mathrm{GA}_{3}\right)$ at a concentration of $150 \mathrm{mg} \cdot \mathrm{dm}^{-3}$ for $30 \mathrm{~min}$. Earlier research by Janowska and Andrzejak [5], Janowska [6], Janowska and Schroeter [19], and Kozłowska et al. [20] showed that this concentration of $\mathrm{GA}_{3}$ was optimal for the 'Albomaculata' cultivar.

The plants were also treated with a commercial product containing a mixture of AMF: Rhizophagus aggregatus (N.C. Schenck and G.S. Sm.), Funneliformis mosseae (T.H. Nicolson \& Gerd.) C. Walker \& A. Schüßler, Rhizophagus intraradices (N.C. Schenck and G.S. Sm.) C. Walker and A. Schüßler, Rhizophagus clarus (T.H. Nicolson and N.C. Schenck) C. Walker and A. Schüßler, Claroideoglomus etunicatum (W.N. Becker and Gerd.) C. Walker and A. Schüßler, and Gigaspora margerita W.N. Becker and I.R. Hall. One week after the planting, the fungi were applied in the form of spores at an amount of 100 propagation units per plant- $2 \mathrm{~g}$ of the product per plant. Each treatment involved five plants in three replications.

\subsection{Cultivation}

The plants were grown in a greenhouse. Fertilization started in the fifth week of cultivation. We applied 0.2\% solutions of Peters Professional (20:20:20) or Brown Superba (14-10-25 + microelements) fertilizers every 10-14 days. At the beginning of vegetation, when the leaves were fully developed, $0.2 \%$ calcium saltpetre was applied foliarly once.

The lengths of the peduncles and spathes were measured, and the yield of inflorescences developing from a single rhizome was determined.

\subsection{Chemical Analysis}

Leaves were dried at a temperature of $45-50{ }^{\circ} \mathrm{C}$ and then ground. To determine the total content of nitrogen $(\mathrm{N})$, phosphorus $(\mathrm{P})$, potassium $(\mathrm{K})$, calcium $(\mathrm{Ca})$, and magnesium $(\mathrm{Mg})$, these leaves were mineralized in concentrated sulphuric acid $\left(\mathrm{H}_{2} \mathrm{SO}_{4}\right)$. The following methods were used to measure the content of the nutrients: total N-by Kjeldahl digestion with distillation in a Parnas-Wagner apparatus, $\mathrm{P}$ - the colorimetric method employing ammonium molybdate (after Schillak), and $\mathrm{K}, \mathrm{Ca}$, and $\mathrm{Mg}$-atomic absorption spectrometry (AAS).

To determine the total iron $(\mathrm{Fe})$, manganese $(\mathrm{Mn})$, zinc $(\mathrm{Zn})$, and copper $(\mathrm{Cu})$, the leaves were mineralized in a mixture of nitric $\left(\mathrm{HNO}_{3}\right)$ and perchloric acids $\left(\mathrm{HClO}_{4}\right)(3: 1$, $v / v)$, and for sodium (Na), in concentrated sulphuric acid $\left(\mathrm{H}_{2} \mathrm{SO}_{4}\right)$ [21]. After the mineralization, the $\mathrm{Na}, \mathrm{Fe}, \mathrm{Mn}, \mathrm{Zn}$, and $\mathrm{Cu}$ contents were determined using the AAS method (on a Carl Zeiss Jena apparatus). 


\subsection{Root Colonisation}

The method described by Phillips and Hayman [22] was used to stain the root mycorrhizas. Root colonization was expressed as the percentage of colonized root lengths versus observed root lengths. The soil hyphal length was measured with the method described by Bethlenfalvay and Ames [23].

\subsection{Data Analysis}

Three-way analysis of variance and the Statistica 8.0 software were used for statistical analysis of the results. The means were grouped with the the Newman-Keuls test.

\section{Results and Discussion}

\subsection{Root Colonisation}

In the three consecutive years of the study the AMF colonization, measured as the percentage of root lengths colonized by hyphae, amounted to $31.2 \%, 32.0 \%$, and $30.7 \%$ in the plants not treated with $\mathrm{GA}_{3}$, whereas, in those treated with $\mathrm{GA}_{3}$, the AMF colonization was $29.9 \%, 31.1 \%$, and $30.4 \%$. The results of the study showed that $\mathrm{GA}_{3}$ did not affect the root colonization by AMF. According to Eloise et al. [24], endogenous levels of gibberellins (GA) influence the formation of arbuscules in mycorrhizated pea roots. The authors suggested that GA suppresses the formation of arbuscules in pea roots; however, exogenous treatment does not enable distinction between occurrences taking place in the rhizosphere and those inside the root cells.

\subsection{Yield and Quality of Flowers}

The yield of flowers significantly depended on mycorrhization only. When the plants were treated with AMF, their average yield of flowers was 100\% greater than that of the non-mycorrhized plants (Table 1). The comparison of interactions showed that the most flowers developed on the mycorrhized plants, irrespective of whether or not their rhizomes had been soaked in $\mathrm{GA}_{3}$. The soaking of rhizomes in $\mathrm{GA}_{3}$ without mycorrhiza boosted the yield of flowers; however, their number was significantly smaller compared with the mycorrhized plants.

The soaking of rhizomes in $\mathrm{GA}_{3}$ is increasingly popular in large-scale production because it improves the flowering of Zantedeschia cultivars $[1-6,25]$. The study showed that $\mathrm{GA}_{3}$ could be replaced with mycorrhiza, which proved to be more effective than the soaking of rhizomes in $\mathrm{GA}_{3}$. Janowska et al. [26] observed that mycorrhization increased the yield of flowers of Zantedeschia albomaculta 'Albomaculata' cultivated in a greenhouse. According to Janowska et al. [27], the mycorrhization of Syningia speciosa cultivars affected only the number of flower buds. After mycorrhization, both the 'Defiance' and 'Blanche de Meru' cultivars yielded significantly more buds ( $66.7 \%$ and $57 \%$, respectively) compared with the control plants.

The addition of mycorrhizal fungi to the substrate stimulated flower bud induction, likely because mycorrhizal fungi produce growth regulators, including those from the gibberellin group [7,8]. According to Nowak [28], mycorrhization had no effect on the abundance of Callistephus chinensis flowers. Lovato et al. [29] noted that mycorrhized miniature roses and chrysanthemums were better-branched, and, as a result, they flowered more abundantly. According to Janowska and Andrzejak [30], Tagetes patula 'Yellow Boy' plants treated with mycorrhiza produced more inflorescence buds, whereas Salvia splendens 'Saluti Red' developed more flowers per inflorescence.

The study showed that mycorrhization and $\mathrm{GA}_{3}$ had favourable effects on the quality of flowers, expressed by the length of peduncles. Regarding the spathes, only the symbiosis with fungi was found to be effective (Table 1). The length of peduncles and spathes in calla lilies is largely a cultivar-related trait. $\mathrm{GA}_{3}$ treatment has been shown to modify it in certain cultivars, e.g., 'Black Eyed Beauty', 'Cameo', and 'Treasure' as was observed by Janowska and Zakrzewski [31]. On the other hand, Janowska and Krause [25], found that 
$\mathrm{GA}_{3}$ was detrimental to the quality of inflorescences, finding that double and triple spathes tended to develop.

Table 1. The yield and quality of the inflorescences of Zantedeschia albomaculata 'Albomaculata' plants after the treatment with $\mathrm{AMF}$ and $\mathrm{GA}_{3}$. The means followed by the same letter do not differ significantly at $\alpha=0.05$.

\begin{tabular}{|c|c|c|c|c|}
\hline \multirow{2}{*}{ Year } & \multirow{2}{*}{ Mycorrhization } & \multicolumn{2}{|c|}{$\mathrm{GA}_{3}\left(150 \mathrm{mg} \cdot \mathrm{mg}^{-3}\right)$} & \multirow{2}{*}{$\begin{array}{c}\text { Mean for } \\
\text { Mycorrhization }\end{array}$} \\
\hline & & No & Yes & \\
\hline \multicolumn{5}{|c|}{ Yield of flowers } \\
\hline I & & $2.2 \mathrm{a}$ & $3.5 \mathrm{~b}$ & \multirow{4}{*}{$2.8 \mathrm{a}$} \\
\hline II & no & $1.9 \mathrm{a}$ & $4.0 \mathrm{~b}$ & \\
\hline III & & $2.1 \mathrm{a}$ & $3.0 \mathrm{~b}$ & \\
\hline I & & $5.8 \mathrm{c}$ & $5.0 \mathrm{c}$ & \\
\hline II & yes & $6.2 \mathrm{c}$ & $5.8 \mathrm{c}$ & \multirow{3}{*}{$5.6 \mathrm{~b}$} \\
\hline III & & $5.4 \mathrm{c}$ & $5.2 \mathrm{c}$ & \\
\hline \multicolumn{2}{|c|}{ Mean for $\mathrm{GA}_{3}$} & $3.9 \mathrm{a}$ & $4.4 \mathrm{a}$ & \\
\hline \multicolumn{5}{|c|}{ Flower peduncle length $(\mathrm{cm})$} \\
\hline I & & $36.0 \mathrm{a}$ & $40.7 \mathrm{~b}$ & \multirow{4}{*}{$39.0 \mathrm{a}$} \\
\hline II & no & $38.0 \mathrm{a}$ & $41.3 \mathrm{~b}$ & \\
\hline III & & $37.8 \mathrm{a}$ & $40.0 \mathrm{~b}$ & \\
\hline I & & $43.2 \mathrm{c}$ & $45.5 \mathrm{~d}$ & \\
\hline II & yes & $44.0 \mathrm{c}$ & $43.7 \mathrm{c}$ & \multirow{3}{*}{$44.3 \mathrm{~b}$} \\
\hline III & & $43.2 \mathrm{c}$ & $46.0 \mathrm{~d}$ & \\
\hline \multicolumn{2}{|c|}{ Mean for $\mathrm{GA}_{3}$} & $40.4 \mathrm{a}$ & $42.9 \mathrm{~b}$ & \\
\hline \multicolumn{5}{|c|}{ Spathe length $(\mathrm{cm})$} \\
\hline I & & $10.0 \mathrm{a}$ & $10.0 \mathrm{a}$ & \multirow{4}{*}{$10.3 \mathrm{a}$} \\
\hline II & no & $10.4 \mathrm{a}$ & $10.6 \mathrm{a}$ & \\
\hline III & & $10.2 \mathrm{a}$ & $10.4 \mathrm{a}$ & \\
\hline I & & $12.2 \mathrm{~b}$ & $11.5 \mathrm{~b}$ & \\
\hline II & yes & $12.0 \mathrm{~b}$ & $12.0 \mathrm{~b}$ & \multirow{3}{*}{$11.7 \mathrm{~b}$} \\
\hline III & & $11.6 \mathrm{~b}$ & $11.0 \mathrm{~b}$ & \\
\hline \multicolumn{2}{|c|}{ Mean for $\mathrm{GA}_{3}$} & $11.0 \mathrm{a}$ & $10.9 \mathrm{a}$ & \\
\hline
\end{tabular}

This effect was not observed in our study, either in the mycorrhized plants or those treated with $\mathrm{GA}_{3}$. According to Janowska et al. [26], Zantedeschia albomaculata inflorescences had longer peduncles after AMF treatment. Nowak and Nowak [32] found that AMF and carbon dioxide $\left(\mathrm{CO}_{2}\right)$ enrichment increased the number of leaves as well as the fresh and dry weights of Osteospermum ecklonis shoots.

\subsection{Content of Macroelements}

$\mathrm{AMF}$ and $\mathrm{GA}_{3}$ had no effect on the content of macroelements in the leaves of the 'Albomaculata' cultivar, with the exception of $\mathrm{Ca}$. Ca is a structurally and functionally essential element in plant physiology. The majority of plant Ca can be found in the cell walls and in the in the vacuoles; however, it is also a key component regulating the functions of the plasma membrane. Ca additionally controls the activity of various key metabolic enzymes [33]. There was a significantly higher $\mathrm{Ca}$ content in the leaves of the plants treated with $\mathrm{AMF}$ and $\mathrm{GA}_{3}$. The leaves of the non-mycorrhized plants whose rhizomes had been soaked in the $\mathrm{GA}_{3}$ had a lower Ca content (Table 2). 
Table 2. The effect of AMF and $\mathrm{GA}_{3}$ (\% DW) on the content of macroelements in the leaves of the Zantedeschia albomaculata 'Albomaculata' plants. The means followed by the same letter do not differ significantly at $\alpha=0.05$.

\begin{tabular}{|c|c|c|c|c|}
\hline \multirow{2}{*}{ Year } & \multirow{2}{*}{ Mycorrhization } & \multicolumn{2}{|c|}{$\mathrm{GA}_{3}\left(150 \mathrm{mg} \cdot \mathrm{mg}^{-3}\right)$} & \multirow{2}{*}{$\begin{array}{c}\text { Mean for } \\
\text { Mycorrhization }\end{array}$} \\
\hline & & No & Yes & \\
\hline \multicolumn{5}{|c|}{$\mathrm{N}$} \\
\hline I & \multirow{6}{*}{ yes } & $5.19 \mathrm{a}$ & $4.79 \mathrm{a}$ & \multirow{4}{*}{$4.93 \mathrm{a}$} \\
\hline II & & $4.90 \mathrm{a}$ & $4.70 \mathrm{a}$ & \\
\hline III & & $5.00 \mathrm{a}$ & $4.99 \mathrm{a}$ & \\
\hline $\mathrm{I}$ & & $4.77 \mathrm{a}$ & $5.11 \mathrm{a}$ & \\
\hline II & & $4.91 \mathrm{a}$ & $4.99 \mathrm{a}$ & \multirow{3}{*}{$4.92 \mathrm{a}$} \\
\hline III & & $4.71 \mathrm{a}$ & $5.00 \mathrm{a}$ & \\
\hline \multicolumn{2}{|c|}{ Mean for $\mathrm{GA}_{3}$} & $4.91 \mathrm{a}$ & $4.93 \mathrm{a}$ & \\
\hline \multicolumn{5}{|c|}{$\mathrm{P}$} \\
\hline I & \multirow{6}{*}{ yes } & $0.43 \mathrm{a}$ & $0.42 \mathrm{a}$ & \multirow{4}{*}{$0.43 \mathrm{a}$} \\
\hline II & & $0.44 \mathrm{a}$ & $0.40 \mathrm{a}$ & \\
\hline III & & $0.45 \mathrm{a}$ & $0.44 \mathrm{a}$ & \\
\hline $\mathrm{I}$ & & $0.42 \mathrm{a}$ & $0.42 \mathrm{a}$ & \\
\hline II & & $0.39 \mathrm{a}$ & $0.41 \mathrm{a}$ & \multirow{3}{*}{$0.41 \mathrm{a}$} \\
\hline III & & $0.43 \mathrm{a}$ & $0.39 \mathrm{a}$ & \\
\hline \multicolumn{2}{|c|}{ Mean for $\mathrm{GA}_{3}$} & $0.43 \mathrm{a}$ & $0.41 \mathrm{a}$ & \\
\hline \multicolumn{5}{|c|}{$\mathrm{K}$} \\
\hline I & \multirow{6}{*}{ yes } & $3.91 \mathrm{a}$ & $3.96 \mathrm{a}$ & \multirow{6}{*}{$3.91 \mathrm{a}$} \\
\hline II & & $3.87 \mathrm{a}$ & $4.00 \mathrm{a}$ & \\
\hline III & & $3.84 \mathrm{a}$ & $3.86 \mathrm{a}$ & \\
\hline I & & $3.68 \mathrm{a}$ & $4.15 \mathrm{a}$ & \\
\hline II & & $3.76 \mathrm{a}$ & $3.97 \mathrm{a}$ & \\
\hline III & & $3.80 \mathrm{a}$ & $3.92 \mathrm{a}$ & \\
\hline \multicolumn{2}{|c|}{ Mean for $\mathrm{GA}_{3}$} & $3.81 \mathrm{a}$ & $3.98 \mathrm{a}$ & \\
\hline \multicolumn{5}{|c|}{$\mathrm{Ca}$} \\
\hline I & \multirow{6}{*}{ yes } & $0.76 \mathrm{~b}$ & $0.66 \mathrm{a}$ & \multirow[b]{6}{*}{$0.80 \mathrm{~b}$} \\
\hline II & & $0.75 \mathrm{~b}$ & $0.64 \mathrm{a}$ & \\
\hline III & & $0.76 \mathrm{~b}$ & $0.62 \mathrm{a}$ & \\
\hline I & & $0.73 \mathrm{~b}$ & $0.85 \mathrm{c}$ & \\
\hline II & & $0.75 \mathrm{~b}$ & $0.90 \mathrm{c}$ & \\
\hline III & & $0.71 \mathrm{~b}$ & $0.87 \mathrm{c}$ & \\
\hline \multicolumn{2}{|c|}{ Mean for $\mathrm{GA}_{3}$} & $0.74 \mathrm{a}$ & $0.76 \mathrm{a}$ & \\
\hline \multicolumn{5}{|c|}{$\mathrm{Mg}$} \\
\hline I & \multirow{6}{*}{ yes } & $0.22 \mathrm{a}$ & $0.24 \mathrm{a}$ & \multirow{6}{*}{$0.23 \mathrm{a}$} \\
\hline II & & $0.25 \mathrm{a}$ & $0.22 \mathrm{a}$ & \\
\hline III & & $0.24 \mathrm{a}$ & $0.26 \mathrm{a}$ & \\
\hline I & & $0.25 \mathrm{a}$ & $0.30 \mathrm{a}$ & \\
\hline II & & $0.27 \mathrm{a}$ & $0.26 \mathrm{a}$ & \\
\hline III & & $0.24 \mathrm{a}$ & $0.29 \mathrm{a}$ & \\
\hline \multicolumn{2}{|c|}{ Mean for $\mathrm{GA}_{3}$} & $0.25 \mathrm{a}$ & $026 \mathrm{a}$ & \\
\hline
\end{tabular}

Janowska et al. [26] found that the leaves of mycorrhized Zantedeschia albomaculata 'Albomaculata' plants contained: $\mathrm{N}-5.35-5.55 \%$ d.w., $\mathrm{P}-0.44 \%$ and $0.53 \% \mathrm{DW}, \mathrm{K}-3.89 \%$ and $4.41 \% \mathrm{DW}, \mathrm{Ca}-0.78 \%$ and $0.80 \%$ d.w., and $\mathrm{Mg}-0.22 \%$ and $0.23 \%$ DW. The mycorrhization had no effect on the content of $\mathrm{Ca}$ and $\mathrm{Mg}$ in Zantedeschia leaves. Nowak [28], observed a slightly elevated P level in the leaves of mycorrhized Callistephus chinensis plants.

However, the mycorrhization did not affect the N, K, or Ca content in this species. Available scientific publications do not provide information how $\mathrm{GA}_{3}$ affects the levels of 
macroelements in Zantedeschia albomaculata leaves. Janowska et al. [34] noted that all GA 3 treatments stimulated the Ca uptake in Gladiolus hybridus 'Black Velvet'; however, they had no effect on the uptake of other macronutrients. Another study conducted by the same authors [35] showed that benzyladenine (BA) applied at $100-600 \mathrm{mg} \cdot \mathrm{dm}^{-3}$ stimulated the Ca uptake in this cultivar but had no effect on the uptake of other macronutrients.

\subsection{Content of Microelements}

Mycorrhization had a favourable effect on the content of the $\mathrm{Na}$ and other microelements, with the exception of Fe (Table 3). Micronutrients as essential components for plant life were discovered in the 1920s and 1930s. Their role is limited to the regulation of biochemical processes taking place in plants during the growing season. This means that plants have a low demand for these components [36]. Microelements have a direct and indirect influence on the flowering and quality of flowers in ornamental plants.

Table 3. Effect of the of AMF and $\mathrm{GA}_{3}\left(\mathrm{mg} \cdot \mathrm{kg}^{-1}\right.$ in DW) on the content of microelements and sodium in the leaves of the Zantedeschia albomaculata 'Albomaculata'. Means followed by the same letter do not differ significantly at $\alpha=0.05$.

\begin{tabular}{|c|c|c|c|c|}
\hline \multirow{2}{*}{ Year } & \multirow{2}{*}{ Mycorrhization } & \multicolumn{2}{|c|}{$\mathrm{GA}_{3}\left(150 \mathrm{mg} \cdot \mathrm{dm}^{-3}\right)$} & \multirow{2}{*}{$\begin{array}{c}\text { Mean for } \\
\text { Mycorrhization }\end{array}$} \\
\hline & & No & Yes & \\
\hline \multicolumn{5}{|c|}{$\mathrm{Fe}$} \\
\hline I & \multirow[b]{2}{*}{ non } & $43.68 \mathrm{a}$ & $42.20 \mathrm{a}$ & \multirow{3}{*}{$43.14 \mathrm{a}$} \\
\hline II & & $43.56 \mathrm{a}$ & $43.42 \mathrm{a}$ & \\
\hline III & \multirow{4}{*}{ yes } & $42.99 \mathrm{a}$ & $43.01 \mathrm{a}$ & \\
\hline $\mathrm{I}$ & & $43.88 \mathrm{a}$ & $42.75 \mathrm{a}$ & \multirow{4}{*}{$43.36 \mathrm{a}$} \\
\hline II & & $43.85 \mathrm{a}$ & $43.21 \mathrm{a}$ & \\
\hline III & & $42.89 \mathrm{a}$ & $43.56 \mathrm{a}$ & \\
\hline \multicolumn{2}{|c|}{ Mean for $\mathrm{GA}_{3}$} & $43.48 \mathrm{a}$ & $43.03 \mathrm{a}$ & \\
\hline \multicolumn{5}{|c|}{$\mathrm{Mn}$} \\
\hline I & \multirow{6}{*}{ yes } & $61.00 \mathrm{a}$ & $60.15 a$ & \multirow{4}{*}{$60.66 \mathrm{a}$} \\
\hline II & & $60.88 \mathrm{a}$ & $61.26 \mathrm{a}$ & \\
\hline III & & $59.79 \mathrm{a}$ & $60.88 \mathrm{a}$ & \\
\hline $\mathrm{I}$ & & $70.53 c$ & $65.15 b$ & \\
\hline II & & $69.73 \mathrm{c}$ & $64.83 \mathrm{~b}$ & \multirow{3}{*}{$67.62 \mathrm{~b}$} \\
\hline III & & $69.99 c$ & $65.51 \mathrm{~b}$ & \\
\hline \multicolumn{2}{|c|}{ Mean for $\mathrm{GA}_{3}$} & $65.32 \mathrm{a}$ & $62.96 \mathrm{a}$ & \\
\hline \multicolumn{5}{|c|}{$\mathrm{Zn}$} \\
\hline I & \multirow{6}{*}{ yes } & $31.60 \mathrm{a}$ & $30.05 \mathrm{a}$ & \multirow{6}{*}{$30.85 \mathrm{a}$} \\
\hline II & & $30.99 a$ & $31.16 \mathrm{a}$ & \\
\hline III & & $30.56 \mathrm{a}$ & $30.78 \mathrm{a}$ & \\
\hline I & & $35.13 \mathrm{~b}$ & $34.28 \mathrm{~b}$ & \\
\hline II & & $34.87 \mathrm{~b}$ & $35.56 \mathrm{~b}$ & \\
\hline III & & $35.15 b$ & $35.26 \mathrm{~b}$ & \\
\hline \multicolumn{2}{|c|}{ Mean for $\mathrm{GA}_{3}$} & $33.05 \mathrm{a}$ & $32.84 \mathrm{a}$ & \\
\hline \multicolumn{5}{|c|}{$\mathrm{Cu}$} \\
\hline $\mathrm{I}$ & \multirow{4}{*}{ non } & $6.73 \mathrm{a}$ & $6.91 \mathrm{a}$ & \multirow{4}{*}{$6.54 \mathrm{a}$} \\
\hline II & & $6.36 \mathrm{a}$ & $6.71 \mathrm{a}$ & \\
\hline III & & $6.16 \mathrm{a}$ & $6.36 \mathrm{a}$ & \\
\hline I & & $7.24 \mathrm{~b}$ & $7.10 \mathrm{~b}$ & \\
\hline II & \multirow[t]{2}{*}{ yes } & $7.31 \mathrm{~b}$ & $7.53 \mathrm{~b}$ & \multirow{3}{*}{$7.25 \mathrm{~b}$} \\
\hline III & & $7.41 \mathrm{a}$ & $7.29 \mathrm{~b}$ & \\
\hline \multicolumn{2}{|c|}{ Mean for $\mathrm{GA}_{3}$} & $6.80 \mathrm{a}$ & $6.98 \mathrm{a}$ & \\
\hline
\end{tabular}


Table 3. Cont.

\begin{tabular}{ccccc}
\hline \multirow{2}{*}{ Year } & Mycorrhization & \multicolumn{2}{c}{$\mathrm{GA}_{\mathbf{3}}\left(\mathbf{1 5 0} \mathbf{~ m g} \cdot \mathbf{d m}^{-\mathbf{3}}\right)$} & \multirow{2}{*}{$\begin{array}{c}\text { Mean for } \\
\text { Mycorrhization }\end{array}$} \\
\cline { 2 - 3 } & & No & Yes & \\
\hline I & Na & $0.05 \mathrm{a}$ & $0.04 \mathrm{a}$ & \\
II & $0.05 \mathrm{a}$ & $0.06 \mathrm{a}$ & $0.05 \mathrm{a}$ \\
III & $0.04 \mathrm{a}$ & $0.05 \mathrm{a}$ & \\
I & yes & $0.05 \mathrm{a}$ & $0.06 \mathrm{a}$ & $0.05 \mathrm{a}$ \\
II & $0.05 \mathrm{a}$ & $0.04 \mathrm{a}$ & \\
III & $0.05 \mathrm{a}$ & $0.05 \mathrm{a}$ & \\
\hline \multicolumn{2}{c}{ Mean for $\mathrm{GA}_{3}$} & $0.05 \mathrm{a}$ & $0.05 \mathrm{a}$ &
\end{tabular}

The accumulation of microelements, except for $\mathrm{Zn}$, in Zantedeschia leaves is a favourable occurrence, as it may result in more abundant inflorescences of higher quality. Janowska et al. [34] found that all $\mathrm{GA}_{3}$ treatments increased the Mn content but did not affect the $\mathrm{Cu}$ content in the leaves of Gladiolus hybridus 'Black Velvet'. $\mathrm{GA}_{3}$ concentrated at $600 \mathrm{mg} \cdot \mathrm{dm}^{-3}$ stimulated the uptake of Fe and $\mathrm{B}$, but lower $\mathrm{GA}_{3}$ concentrations inhibited the uptake of both microelements.

The Zn uptake was stimulated at $100 \mathrm{mg} \cdot \mathrm{dm}^{-3}$; however, it was inhibited at a higher concentration. Janowska et al. [35] observed that another growth regulator-BA-applied at $600 \mathrm{mg} \cdot \mathrm{dm}^{-3}$, stimulated the uptake of $\mathrm{Mn}$ and $\mathrm{Zn}$ in G. hybridus 'Black Velvet', whereas, at concentrations ranging from 100 to $600 \mathrm{mg} \cdot \mathrm{dm}^{-3}$, it stimulated the B uptake but inhibited the Cu uptake. Walker et al. [37] observed a similar phenomenon in Betula lenta leaves. Janowska et al. [26] found that mycorrization only affected the Mn content in Zantedeschia albomaculata leaves but had no effect on the content of $\mathrm{Na}$ and other microelements. Nowak [28] noted elevated levels of $\mathrm{Mg}$ in the leaves of Callistephus chinensis after the treatment with mycorrhizal fungi.

\section{Conclusions}

AMF increased the yield of Zantedeschia albomaculata 'Albomaculata' inflorescences by $100 \%$.AMF and $\mathrm{GA}_{3}$ had a favourable effect on the quality of inflorescences, expressed by the length of peduncles, whereas mycorrhization on its own positively affected the length of the spathes. AMF and $\mathrm{GA}_{3}$ had no effect on the level of macroelements in calla lily leaves, with the exception of calcium. The leaves of mycorrhized plants had a high content of $\mathrm{Na}$ and micronutrients, except for Fe. The results of the study showed that $\mathrm{GA}_{3}$ could be replaced by mycorrhiza when applied to Zantedeschia plants.

Author Contributions: Conceptualization, Methodology, Formal Analysis, Writing, R.A. and B.J. All authors have read and agreed to the published version of the manuscript.

Funding: This research received no external funding.

Institutional Review Board Statement: Not applicable.

Informed Consent Statement: Not applicable.

Data Availability Statement: Not applicable.

Acknowledgments: The publication was co-financed within the framework of Ministry of Science and Higher Education programme as "Regional Initiative Excellence" in years 2019-2022, Project No. 005/RID/2018/19, financing amount 12000000 PLN.

Conflicts of Interest: The authors declare no conflict of interest. 


\section{References}

1. Funnell, K.A.; Tjia, B.O. Effect of storage temperature, duration and gibberellic acid on the flowering of Zantedeschia elliottiana and Z. 'Pink Satin'. J. Am. Soc. Hort. Sci. 1988, 113, 860-863.

2. Corr, B.E.; Widmer, R.E. Paclobutrazol, gibberellic acid and rhizome size affect growth and flowering of Zantedeschia. HortScience 1991, 26, 133-135. [CrossRef]

3. Funnell, K.A.; Mackay, B.R.; Lawoko, C.R.O. Comparative effects of promalin and $\mathrm{ga}_{3}$ on flowering and development of Zantedeschia 'galaxy'. Acta Hort. 1992, 292, 173-179. [CrossRef]

4. Dennis, D.; Doreen, D.J.; Ohteki, T. Effect of a gibberellic acid 'quick-dip' and storage on the yield and quality of blooms from hybrid Zantedeschia tubers. Sci. Hortic. 1994, 57, 133-142. [CrossRef]

5. Janowska, B.; Andrzejak, R. Effect of gibberellic acid spraying and soaking of rhizomes on the growth and flowering of calla lily (Zantedeschia Spreng.). Acta Agrob. 2010, 63, 155-160. [CrossRef]

6. Janowska, B. Effect of growth regulators on flower and leaf yield of the Calla lily (Zantedeschia Spreng.). Hort. Sci. 2013, 40, 78-82. [CrossRef]

7. Ravensdale, M.; Blom, T.J.; Gracia-Garza, J.A.; Svirce, A.M.; Smith, R.J. Bacteriophages and the control of Erwinia carotovora subsp. Carotovora. Can. J. Plant Pathol. 2007, 29, 121-130. [CrossRef]

8. Matysiak, B. Effect of endomycorrhizal inocula during propagation on the growth following transplanting of Ilex $\mathrm{x}$ meserveae 'Blue Boy' cutting. Zesz. Probl. Post. Nauk Roln. 2009, 539, 499-506.

9. Feijen, F.A.A.; Vos, R.A.; Nuytinck, J.; Merckx, V.S.F.T. Evolutionary dynamics of mycorrhizal symbiosis in land plant diversification. Sci. Rep. 2018, 8, 10698. [CrossRef] [PubMed]

10. Gianinazzi, S.; Gollotte, A.; Binet, M.N.; van Tuinen, D.; Redecker, D.; Wipf, D. Agroecology the key role of arbuscular mycorrhizas in ecosystem services. Mycorrhiza 2010, 20, 519-530. [CrossRef]

11. Sbrana, C.; Avio, L.; Giovannetti, M. Beneficial mycorrhizal symbionts affecting the production of health-promoting phytochemicals. Electrophoresis 2014, 35, 1535-1546. [CrossRef]

12. Avio, L.; Turrini, A.; Giovannetti, M.; Sbrana, C. Designing the ideotype mycorrhizal symbionts for the production of healthy food. Front. Plant Sci. 2018, 9, 1089. [CrossRef]

13. Giovannetti, M.; Sbrana, C.; Avio, L.; Citernesi, A.S.; Logi, C. Differential hyphal morphogenesis in arbuscular mycorrhizal fungi during pre-infection stages. New Phytol. 1993, 125, 587-593. [CrossRef]

14. Akiyama, K.; Matsuzaki, K.I.; Hayashi, H. Plant sesquiterpenes induce hyphal branching in arbuscular mycorrhizal fungi. Nature 2005, 435, 824-827. [CrossRef] [PubMed]

15. Sbrana, C.; Giovannetti, M. Chemotropism in the arbuscular mycorrhizal fungus Glomus mosseae. Mycorrhiza 2005, 15, 539-545. [CrossRef]

16. Jiang, Y.; Wang, W.; Xie, Q.; Liu, N.; Liu, L.; Wang, D.; Zhang, X.; Yang, C.; Chen, X.; Tang, D.; et al. Plants transfer lipids to sustain colonization by mutualistic mycorrhizal and parasitic fungi. Science 2017, 356, 1172-1175. [CrossRef] [PubMed]

17. Luginbuehl, L.H.; Menard, G.N.; Kurup, S.; Van Erp, H.; Radhakrishnan, G.V.; Breakspear, A.; Oldroyd, G.E.D.; Eastmond, P.J. Fatty acids in arbuscular mycorrhizal fungi are synthesized by the host plant. Science 2017, 356, 1175-1178. [CrossRef] [PubMed]

18. Maillet, F.; Poinsot, V.; André, O.; Puech-Pagès, V.; Haouy, A.; Gueunier, M.; Cromer, L.; Giraudet, D.; Formey, D.; Niebel, A.; et al. Fungal lipochitooligosaccharide symbiotic signals in arbuscular mycorrhiza. Nature 2011, 469, 58-63. [CrossRef]

19. Janowska, B.; Schroeter, A. The influence of gibberellic acid on flowering of Zantedeschia elliottiana (W. Wats.) Engl. 'Black Magic'. Zesz. Probl. Post. Nauk Roln. 2002, 483, 93-99.

20. Kozłowska, M.; Rybus-Zając, M.; Stachowiak, J.; Janowska, B. Changes in carbohydrate contents of Zantedeschia leaves under gibberellin-stimulated flowering. Acta Physiol. Plant. 2007, 29, 27-32. [CrossRef]

21. Kamińska, W.; Kardasz, T.; Strahl, A.; Bałucka, T.; Walczak, K.; Filipek, P. The Methods of Analisis in Chemical-Agricultural Station. Part II. Analisis of Plants; IUNG: Puławy, Poland, 1972.

22. Phillips, J.M.; Hayman, D.S. Improved procedures for clearing roots and staining parasitic and vesicular-arbuscular mycorrhizal fungi for rapid assessment of infection. Trans. Br. Mycol. Soc. 1970, 55, 158-161. [CrossRef]

23. Bethlenfalvay, G.J.; Ames, R.N. Comparison of two methods for quantifying extraradical mycelium of vesicular arbuscular mycorrhizal fungi. Soil Sci. Soc. Am. J. 1987, 51, 834-837. [CrossRef]

24. Eloise, F.; Ross, J.J.; Jones, W.T.; Reid, J.B. Plant hormones in arbuscular mycorrhizal symbioses: An emerging role for gibberellins. Ann. Bot. 2013, 111, 769-779. [CrossRef]

25. Janowska, B.; Krause, J. The influences of tuber treatment by gibberellic acid on the flowering of Zantedeschia. Rocz. AR Pozn. Ogrodn. 2001, 33, 61-67.

26. Janowska, B.; Andrzejak, R.; Kosiada, T.; Trelka, T.; Frąszczak, B. Effect of mycorrhization on the flowering of the Zantedeschia albomaculata /Hook./ Baill. cv. Albomaculata. Hort. Sci. 2013, 40, 126-130. [CrossRef]

27. Janowska, B.; Rybus-Zajac, M.; Horojdko, M.; Andrzejak, R.; Siejak, D. The effect of mycorrhization on the growth, flowering, content of chloroplast pigments, saccharides and protein in leaves of Sinningia speciosa (Lodd.) Hiern. Acta Agroph. 2016, 23, 213-223.

28. Nowak, J. Effects of mycorrhization and phosphorus nutrition on nutrient uptake, growth and flowering of China aster (Callistephus chinensis /L./ Nees) cultivated on ebb-and-flow benczes. Acta Agrob. 2009, 62, 77-81. [CrossRef] 
29. Lovato, P.E.; Gianinazzi-Pearson, V.; Trouvelot, A.; Gianinzzi, S. The state of art of mycorrhizas and micropropagation. Adv. Hort. Sci. 1996, 10, 46-52.

30. Janowska, B.; Andrzejak, R. Effect of mycorrhizal inoculation on development and flowering of Tagetes patula L. 'Yellow Boy' and Salvia splendens Buc'hoz ex Etl. 'Saluti Red'. Acta Agrob. 2017, 70, 1703. [CrossRef]

31. Janowska, B.; Zakrzewski, P. The effect of gibberellic acid and rhizome treatment on flowering of calla lily (Zantedeschia Spreng.). Zesz. Probl. Post. Nauk Roln. 2006, 510, 223-233.

32. Nowak, J.; Nowak, J.S. $\mathrm{CO}_{2}$ enrichment and mycorrhizal effects on cutting growth and some physiological traits of cuttings during rooting. Acta Sci. Pol. Hort. Cult. 2013, 12, 67-75.

33. Medaj, A.; Piechura, K.; Skrobot, K.; Sokulski, S. Determination of assimilable calcium for plants in the soil of the Kluczwoda Valley by atomic absorption spectrometry. Analit 2017, 3, 50-55.

34. Janowska, B.; Andrzejak, R.; Kosiada, T.; Kwiatkowska, M.; Smolińska, D. The flowering and nutritional status of Gladiolus hybridus 'Black Velvet' following gibberellin treatment. Hortic. Sci. 2018, 45, 205-210. [CrossRef]

35. Janowska, B.; Andrzejak, R.; Kosiada, T.; Kwiatkowska, M.; Smolińska, D. The flowering and nutritional status of Gladiolus hybridus cv. Black Velvet following a cytokinin treatment. J. Element. 2018, 23, 1119-1128. [CrossRef]

36. Spiak, Z. Microelements in agriculture. Zesz. Probl. Post. Nauk Roln. 2000, 471, 29-34.

37. Walker, R.F.; Mclaughlin, S.B.; Amundsen, C.C. Interactive Effects of mycorrhization and fertilization on growth, nutrition and water relation of Sweet Birch. J. Sustain. Forest. 2003, 17, 55-80. [CrossRef] 